\title{
JUURNAL_RU
}

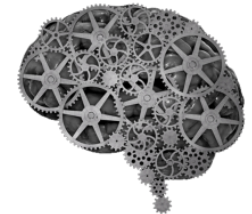

COMPANY GROUP "INTELLEKT"

\author{
Быкова В.В., Цай Л.А. \\ Ростовский государственный медицинский университет \\ Ростов-на-Дону, Россия
}

doi: 10.18411/lj2016-3-11

\section{Хирургические вмешательства у больных с носовыми кровотечениями}

Носовые кровотечения (НК) занимают первое место по частоте среди спонтанных кровотечений [1]. Нередко НК носят упорный, рецидивирующий, характер [2]. В этих случаях консервативные методы лечения, как правило, не дают эффекта, что требует расширения показаний к применению хирургических способов остановки НК $[3,4,5]$.

Наиболее распространенными хирургическими вмешательствами при рецидивирующих НК являются подслизистая резекция перегородки носа, хирургическая отслойка мукоперихондрия, хирургическое блокирование кровоточащих сосудов в виде ангиотомии или сегментирования. Подслизистая резекция перегородки носа показана в тех случаях, когда источник кровотечения локализуется в труднодоступной области шипа или гребня или он не обозрим из-за выраженной деформации перегородки носа. В этих случаях обеспечить эффективную тампонаду носа удается только после устранения указанных деформаций.

Возможности обнаружения источника кровотечения в задних отделах полости носа и прямого воздействия на него значительно расширились с внедрением в ринологическую практику эндоскопических методов исследования. Эндоскопическое исследование полости носа часто позволяют найти и коагулировать кровоточащий сосуд при первичном обращении, что 
избавляет больного от тампонады носа. Если место кровотечения не удается обнаружить, можно коагулировать все венозное сплетение дна полости носа, нижнего и среднего носовых ходов, нижней и средней раковин [6].

Целью нашего исследования было изучение эффективности хирургических вмешательств на перегородке носа у больных с рецидивирующими НК различной этиологии. Хирургические вмешательства произведены 28 больным в возрасте от 16 до 59 лет. Причиной рецидивирующих НК были гипертоническая болезнь - у 13 больных, травмы - у 9 больных, атеросклероз - у 3 больных, тромбоцитопатия - у 2 больных, у 1 больного наблюдались кровотечения из варикозных сосудов в передней трети перегородки носа.

В группу больных с рецидивирующими носовыми кровотечениями на фоне гипертонической болезни включены 10 женщин и 3 мужчин в возрасте от 45 до 66 лет. Возникновению кровотечения предшествовал подъем АД от 200/100 до 240/110 мм рт ст. У 6 больных НК повторялись в течение 3-7 дней до поступления в стационар, остальные были госпитализированы при первичном возникновении кровотечения. В приемном отделении всем больным была произведена передняя тампонада носа и назначена гипотензивная и седативная терапия. Однако после удаления тампонов у всех больных кровотечение возобновилось либо непосредственно после их извлечения (у одного больного), либо через несколько часов (у 12 больных) и неоднократно повторялось на протяжении 3-8 дней, иногда по несколько раз в сутки, даже после стабилизации АД на привычных для больного цифрах. При каждом эпизоде кровотечения применяли марлевую (переднюю или заднюю) или пневматическую тампонаду. Задняя тампонада производилась 7 больным, причем четырем больным повторно.

В группу больных с посттравматическими рецидивирующими НК включено 2 женщины и 7 мужчин в возрасте от 16 до 52 лет. У всех больных выявлены переломы костей носа, кровотечение наблюдалось из задних отделов 
полости носа. Обращает на себя внимание, что у 5 больных НК возникло сразу после травмы, самостоятельно остановилось, а затем возобновилось по прошествии нескольких суток: у 2 больных - через 2 дня, у 2 - через 4,5,и 7 дней и приняло рецидивирующий характер, что потребовало неоднократной тампонады, как передней (2 больных), так и задней (7 больных).

Больные с тромбоцитопатией и варикозным расширением сосудов перегородки носа страдали так называемыми «привычными» НК.

Для профилактики рецидивов НК 10 больным произведена подслизистая резекция перегородки носа, 9 больным - хирургическая отслойка мукоперихондрия, в 9 случаях произведена диатермокоагуляция кровоточащих сосудов под контролем эндоскопа. После удаления тампонов из носа кровотечение не наблюдалось ни в одном случае, однако, при дальнейшем наблюдении отмечено возобновление носовых кровотечений у больных с тромбоцитопатией.

Помимо этого, в анализируемую группу включено 2 больных наследственной геморрагической телеангиэктазией (болезнью Рандю-Ослера), которым в прошлом была произведена подслизистая резекция перегородки носа и хирургическая отслойка мукоперихондрия. У этих больных хирургические вмешательства оказались неэффективными и НК повторялись с прежней частотой. Наши данные совпадают с результатами, полученными другими авторами.

В литературе имеется сообщение об успешной остановке тяжелого рецидивирующего носового кровотечения применением частичной подслизистой резекции перегородки носа у ребенка с нарушениями свертывающей системы крови, обусловленной тромбастенией Гланцмана [7], но этот случай приведен как казуистическое наблюдение. Что же касается другого системного заболевания-наследственной геморрагической телеангиэктазии (болезни Рандю-Ослера-Вебера), то данная патология оказывается резистентной к традиционно применяемым хирургическим методам лечения НК, в том числе и 
к операциям на перегородке носа $[8,9]$.

Таким образом, хирургические вмешательства при рецидивирующих носовых кровотечениях, обусловленных тромбоцитопатией и болезнью РандюОслера нецелесообразны ввиду их низкой эффективности.

\section{Литература:}

1. Пальчун В.Т., Кунельская Н.А., Кислова Н.М. Экстренная патология носа и околоносовых пазух. Вестн. оторинолар. 1998; 3: 4-12.

2. Бойко Н.В., Колмакова Т.С., Быкова В.В. Биохимические показатели анемии у больных с носовыми кровотечениями. Вестник оторинолар. 2010; 4: $13-16$.

3. Бойко Н.В. Хирургическое лечение рецидивирующих носовых кровотечений. Рос. ринология 1999; 2: 29.

4. Бойко Н.В., Шатохин Ю.В., Быкова В.В. Патогенетическое лечение рецидивирующих носовых кровотечений на фоне гипертонической болезни. Рос. ринология 2007; 2: 58.

5. Волков А.Г., Бойко Н.В., Быкова В.В., Жданов В.Г. Совершенствование способов остановки носового кровотечения. Вестник оторинолар. 2010; 4: 9 12.

6. Wurman L.H., Sack J.G., Paulson T.O., Flannery J.V. Selective endoscopic electrocautery for posterior epistaxis. Laryngoscope 1988; 98 (12): 1348-1349.

7. Guarisco J.L., Cheney M.L., Le Jeune F.E. et al. Limited septoplasty as treatment of reccurent epistaxis in a child with Glanzmann's tthrombasthenia. Laryngoscope1987; 97 (3): 336-338.

8. Rebeiz E.E., Bryan D.J., Ehrlichman R.J., Shapshay S.M. Surgical management of life-threatening epistaxis in Osler-Weber-Rendu disease. Ann.Plastic Surg.1995; 35(2): 208-213.

9. Gifford T.O., Orlandi R.R. Epistaxis. Otolaryngol Clin N Am. 2008; 41: 525536. 